\title{
Effect of S\&P500's return on emerging markets: Turkish experience
}

\section{Hakan Berument \& Onur Ince}

To cite this article: Hakan Berument \& Onur Ince (2005) Effect of S\&P500's return on emerging markets: Turkish experience, Applied Financial Economics Letters, 1:1, 59-64, DOI: 10.1080/1744654052000314662

To link to this article: https://doi.org/10.1080/1744654052000314662

曲 Published online: 16 Aug 2006.

Submit your article to this journal $\pi$

Џ Article views: 64

Citing articles: 11 View citing articles 


\title{
Effect of S\&P500'S return on emerging markets: Turkish experience
}

\author{
Hakan Berument* and Onur Ince \\ Department of Economics, Bilkent University, 06800 Ankara, Turkey
}

This study assesses the effect of S\&P500 return on the Istanbul Stock Exchange within a dynamic framework. In order to capture the effect, a block recursive VAR model is built, allowing that S\&P500 affects the ISE returns with its current and lag values but not vice versa. The estimates from daily data suggest that returns on S\&P500 affect ISE return positively up to four days.

\section{Introduction}

World economies and financial markets are becoming increasingly interconnected in today's world. The globalization process helps to speed up this interconnection. Therefore, analysis of this interrelation becomes important for both portfolio managers and academics in the global era. In order to see the importance of interconnection in financial markets, the relationship between the US stock market and the Turkish stock market was examined using daily data for the period from 1987 to 2004. The S\&P500 index and the ISE100 index for the US and Turkish stock markets were used, respectively. The model incorporates the assumption that returns on S\&P500 affect the return on ISE100 but not vice versa. In order to incorporate and capture the dynamic relationship among prospective returns, a block recursive VAR was used as in Zha (1999). It was found that an innovation in the S\&P500 return increases the ISE100 return for up to four days in a statistically significant fashion.

Research on the interaction between global stock markets and US stock markets provides various results. Eun and Shim (1989) found that US equity markets affect world markets. They argued that the
USA is the most dominant market in the world. Tokic (2003) found a long run relationship between the USA and five markets; Australia, Japan, Hong Kong, New Zealand and Singapore. According to Cheung and Mak (1992), Liu and Pan (1997), $\mathrm{Wu}$ and Su (1998), both US and Japanese stock markets affect Asian countries. Cha and Oh (2000) reported that Japanese and US markets affect Hong Kong, Korea, Singapore and Taiwan. Gilmore and McMannus (2002) found a correlation between the USA and three central European markets: the Czech Republic, Hungary and Poland. Kasa (1992) and Arshanapalli and Doukas (1993) found bivariate co-integration of European Markets and the USA. Sewell et al. (1996) provided varying degrees of integration between Pacific Rim equity markets and the USA. Ghosh et al. (1999) found that the USA shares a long run equilibrium relationship with Hong Kong, India, Korea and Malaysia. Some studies also elaborate on the time-varying nature of the USA and other stock markets. Eun and Shim (1989) and Arshanapalli and Doukas (1993) reported that US and global financial markets have stronger correlation, especially after the October 1987 collapse in US financial markets. Although relationships between the USA and other stock markets were

*Corresponding author. E-mail: berument@bilkent.edu.tr 
found in the research mentioned above, some studies are opposed to the idea of interaction between stock markets. Ghosh et al. (1999) could not find any effect of the USA and Japan on the stock markets of Taiwan and Thailand. Byers and Peel (1993) and Kanas (1998) found no linkage between US and European markets, constituted by both developed and emerging markets. Felix et al. (1998) found no long run co-movement between the USA and a number of emerging markets.

The research cited above examines relationships between stock markets, including those of emerging markets, using two alternative approaches: Cointegration tests and Vector Autoregressive (VAR) models. Co-integration tests capture any long-run relationships among the stock markets but these tests do not allow for short-term interaction. However, the VAR technique allows dynamic interactions among markets. This paper uses the VAR model in order to assess short-term correlations and capture dynamic interaction.

While correlation between US stock markets and a number of emerging markets had not been found in many studies, assessing any correlation between US stock markets and the Turkish stock market is a worthwhile exercise. Turkey is distinct from other liberalized emerging markets in important aspects. Turkey has been liberalizing her economy since the early 1980s. Although never experiencing hyperinflation, as some Latin American economies, Turkey has had persistent inflation at considerably high and varying levels for about three decades because of the unstable political and social environment. The importance of the stock market in the overall economic activity grows, as indicated by the rise in stock market capitalization from $12.6 \%$ of GDP in 1990 to $34.8 \%$ in 2000 . These features distinguish the Turkish stock market from the emerging markets that constitute the foundation of the research mentioned above.

The outline of this paper is as follows; Section II elaborates on the methodology and provides the empirical evidence. Finally, the paper is concluded in the last section.

\section{Methodology}

A model, similar to the structural vector autoregressive (SVAR) model proposed by Cushman and Zha (1997) is used to examine the effect of a large economy's stock exchange movement on a small economy's stock exchange movement. The foreign stock exchange index follows its own dynamics (an AR process is used as a proxy). Turkish stock exchange movements are affected by its own lag and movements of the foreign stock exchange. Therefore, the foreign stock exchange can be thought to have an exogenous affect on the Turkish stock exchange. None of the lag variables of the Turkish stock exchange determine foreign stock exchange; however, lag values and spot values of the foreign stock exchange affect Turkish stock exchange movement.

The VAR model has some advantages relative to the single equation model since the VAR model allows dynamic interactions among variables and the VAR model has predictive power compared to the single equation model. VAR with block exogeneity is also used since in conventional VAR; stock exchange movements of foreign markets are affected by domestic stock exchanges including lag values. By block exogeneity, this problem is overcome.

The general specification of the identified VAR model of Cushman and Zha (1997) is:

$$
A(L) y(t)=\varepsilon(t)
$$

in which, the $A(L)$ is an $m \times m$ matrix polynomial in the lag operator $L, y(t)$ is the $m \times 1$ observations vector, and $\varepsilon(t)$ is the $m \times 1$ vector of structural disturbances. Equation 2 shows the specification of the model.

$$
\begin{aligned}
& y(t)=\left[\begin{array}{l}
y_{1}(t) \\
y_{2}(t)
\end{array}\right], \quad A(L)=\left[\begin{array}{cc}
A_{11}(L) & 0 \\
A_{21}(L) & A_{22}(L)
\end{array}\right], \\
& \varepsilon(t)=\left[\begin{array}{l}
\varepsilon_{1}(t) \\
\varepsilon_{2}(t)
\end{array}\right] .
\end{aligned}
$$

In Equation 2, it is assumed that $\varepsilon(t)$ is uncorrelated with $y(t-j)$ for $j>0$ and $A(0)$ is non-singular. Block exogeneity is represented by $A_{12}(L)$ in the matrix, which is zero. This means that $y_{1}(t)$ is exogenous to the second block both simultaneously and also for lagged values. To calculate the standard errors of the impulse response functions, the modified error bands of Bernanke et al. (1996) are used for the maximum likelihood estimation (MLE). ${ }^{1}$

The observation matrices are such that $y_{1}=[$ Foreign Stock Exchange $], y_{2}=[$ Domestic Stock Exchange] and the lag order of the identified VAR model is 5 as suggested by Bayesian information

\footnotetext{
${ }^{1}$ See Sims (1986) and Gordon and Leeper (1994).
} 


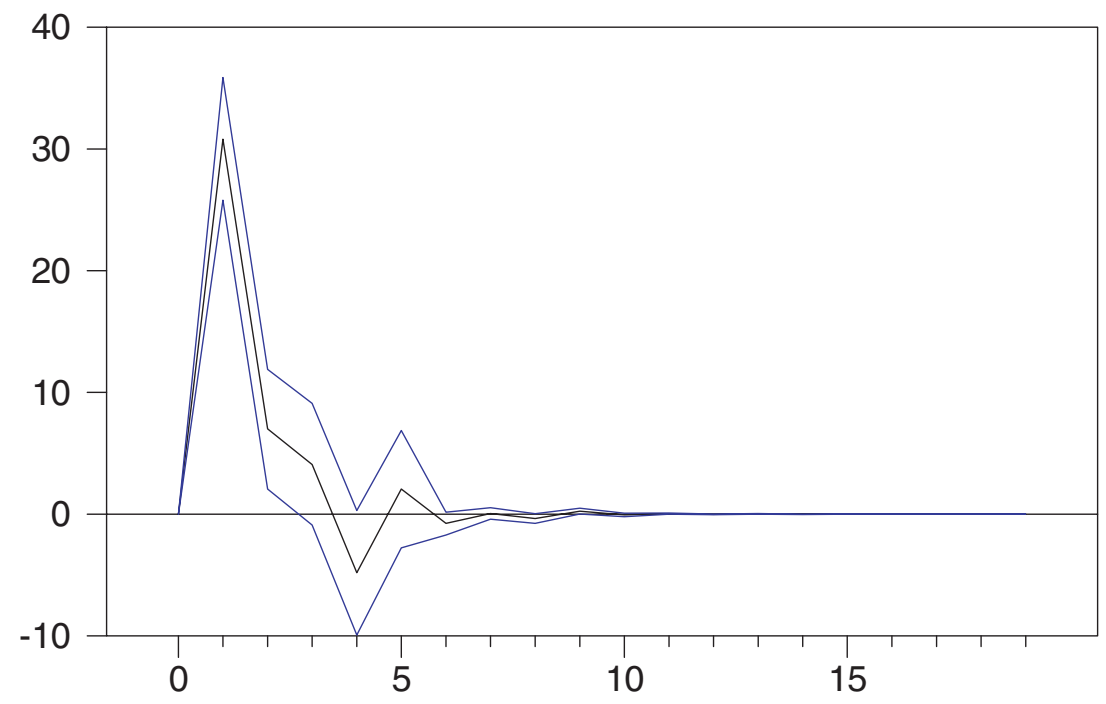

Fig. 1. Response of the ISE100 to the S\&P500 for the full sample

criteria. All error bands in this study were generated with 5000 Monto Carlo draws.

The period, starting from the establishment of the Istanbul Stock Exchange on 23 October 1987 to 8 July 2004, has many interruptions, so various subperiods have been considered for the analysis. The major break periods were: the financial crisis in April 1994; the beginning of the disinflation programme in December 1999; the financial crises in November 2000 and in February 2001; the 11 September 2001 terrorist attack on the twin towers in the USA, which also affected the ISE; the memorandum crisis in the Turkish Parliament, when logistic support for the USA in war with Iraq was refused in February 2003.

The corresponding impulse responses are reported in the figures. Figure 1 reports the impulse response functions for 20 days regarding how the ISE100 returns responded to a one-standard deviation shock to S\&P500 returns by considering the full sample period. The middle line is for impulse responses and the other two lines are for the confidence bonds at $90 \%$ level of confidence bonds. It is important to recognize that a shock to the S\&P500 does not affect the ISE100 return contemporaneously. The main reason for this is that when the NYSE closes, it is the beginning of the next day in the ISE (the time difference between Istanbul and New York being 7 hours). However, a positive shock on the S\&P500 index causes a change on the ISE100 for 6 days and also causes an increase in the ISE100 index for 2.5 days in a statistically significant manner.
Figures 2 to 7 report the impulse responses for different sub samples. Except for the period between 1 January 2002 to 28 February 2003, a statistically significant effect of the S\&P500 returns on the ISE100 returns is observed. It is not surprising that the adaptation of the new government and their struggle with the memorandum to give logistic support to the USA for the war in Iraq caused uncertainty in the Turkish market, so the effect of the S\&P500 on the ISE100 was not observed in that period. In general, for all sub-samples, except for Fig. 6, a one standard deviation shock to the S\&P500 caused an increase in the ISE100 returns in a significant manner. However, the effect of the shock continued for 16 days at most as shown in Fig. 5.

\section{Conclusion}

Interactions among stock markets, increasing with globalization process, encourage economists to assess whether any relationships exist. This study examines the effect of US stock exchange performance on the Turkish stock exchange. The S\&P500 index is used for the US stock exchange and the ISE100 index for the Turkish stock exchange. It is assumed that US stock exchange performance is not affected by Turkish stock market; however, the Turkish stock exchange is affected by both its own dynamics and the US stock exchange. This assumption is reflected in the specification by using the Block recursive VAR model. 


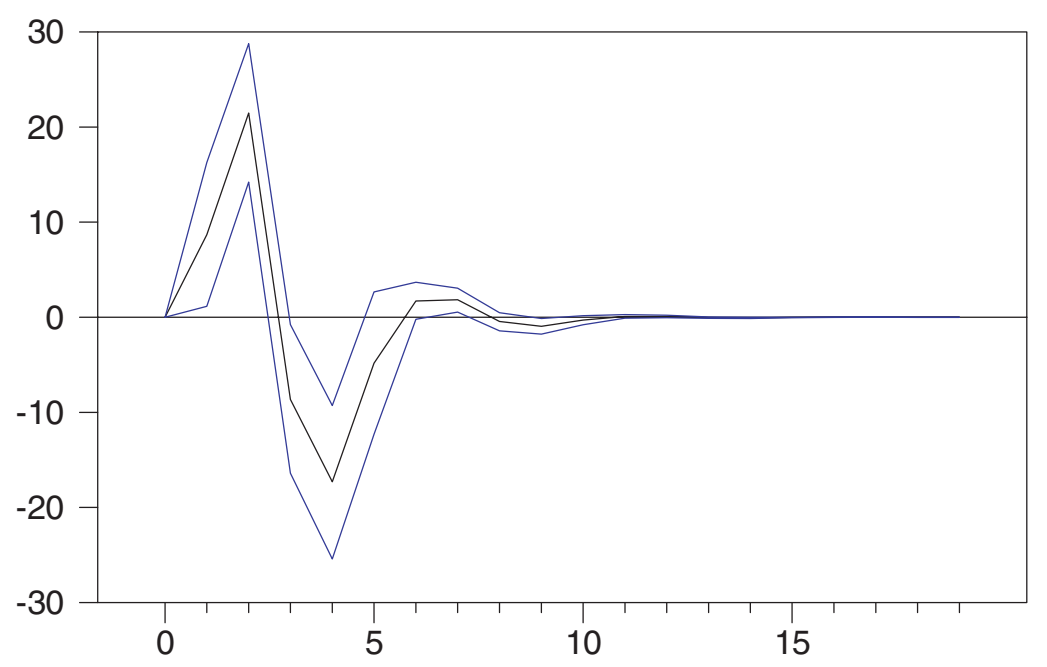

Fig. 2. Response of the ISE100 to the S\&P500 from 23 October 1987 to 1 December 1993

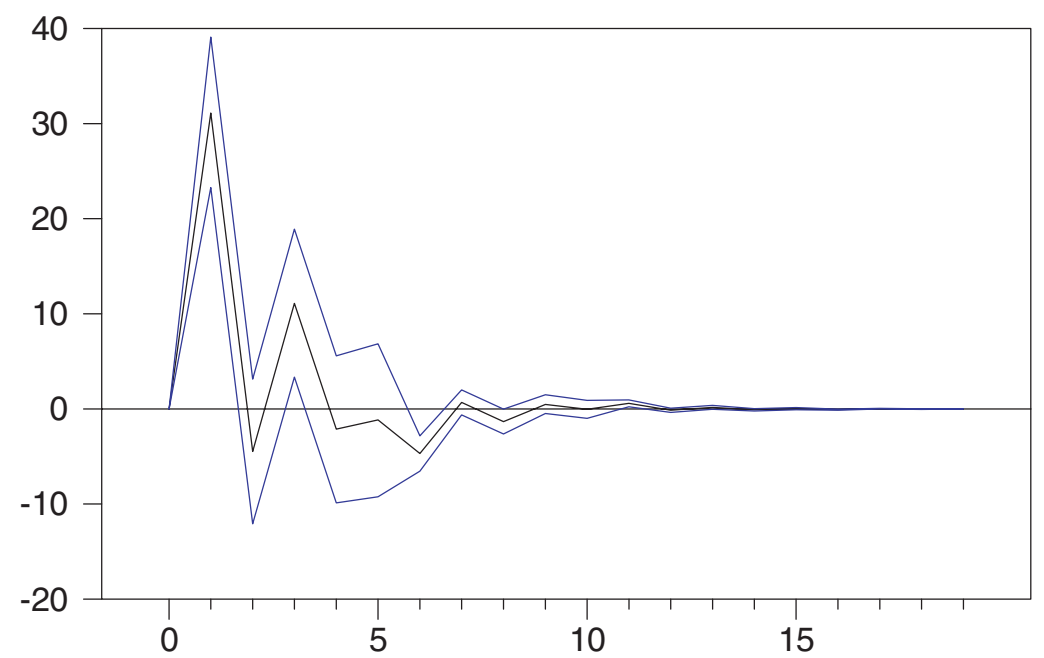

Fig. 3. Response of the ISE100 to the S\&P500 from 01 June 1994 to 1 December 1999

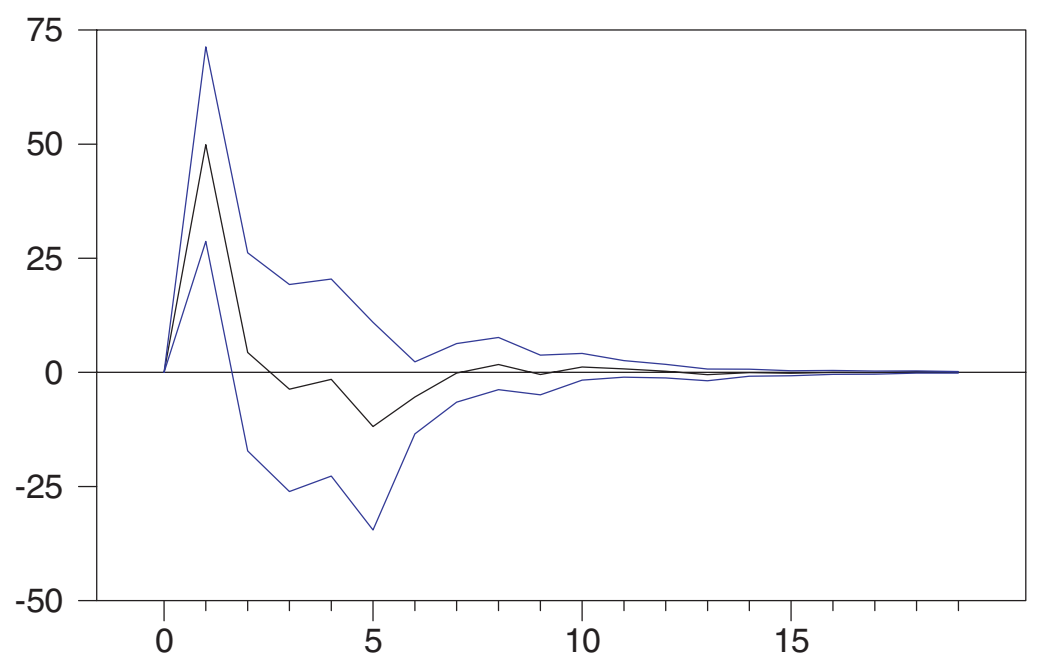

Fig. 4. Response of the ISE100 to the S\&P500 from 1 January 2000 to 1 November 2000 


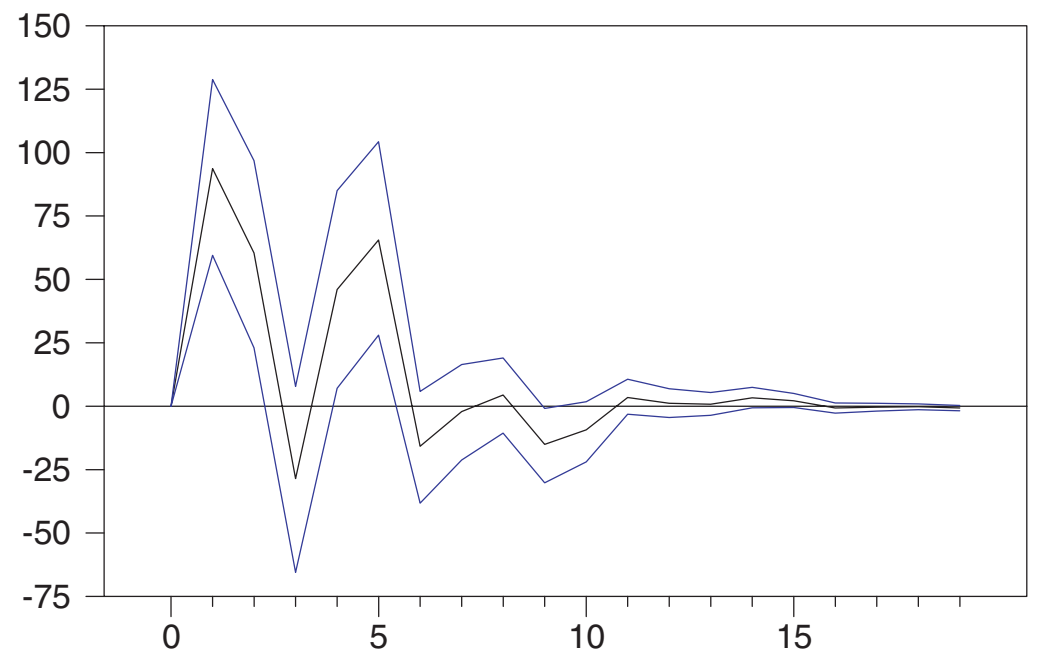

Fig. 5. Response of the ISE100 to the S\&P500 from 13 March 2001 to 10 September 2001

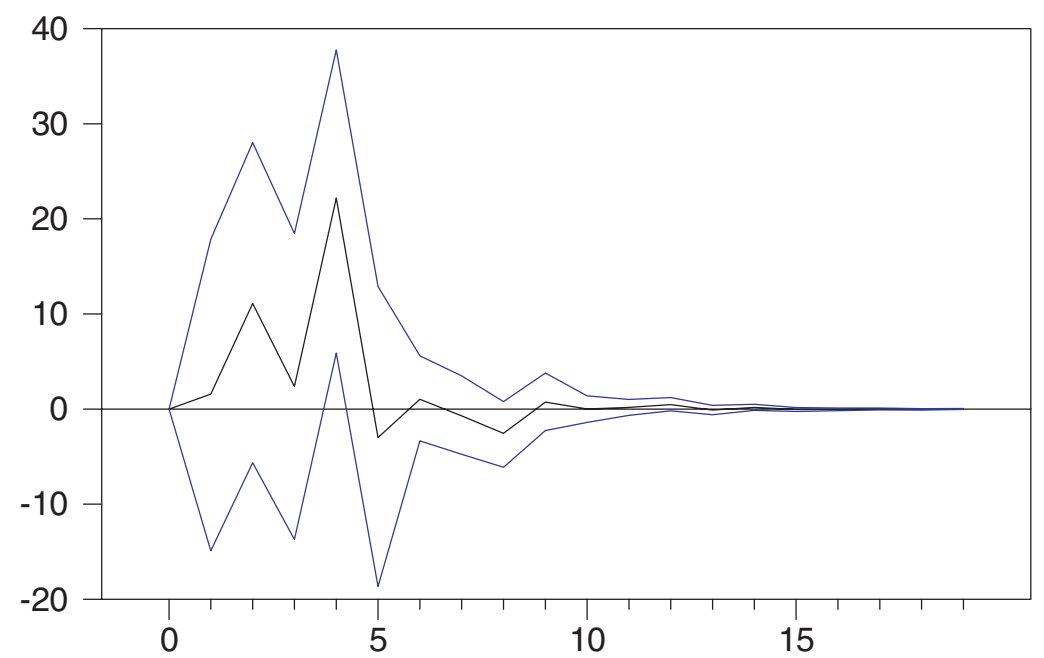

Fig. 6. Response of the ISE100 to the S\&P500 from 1 January 2002 to 28 February 2003

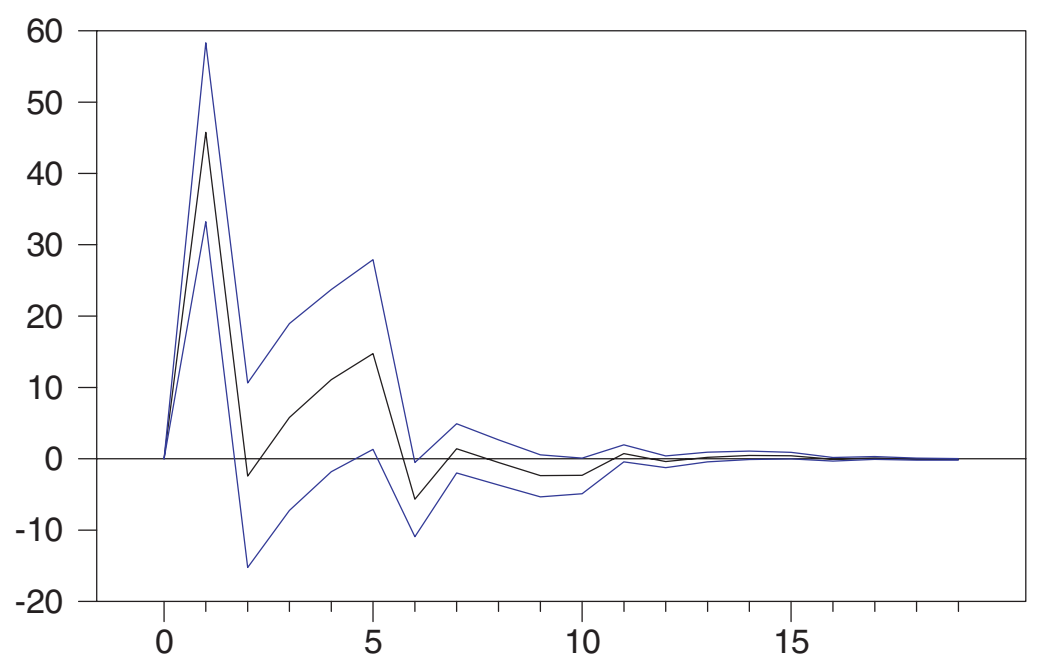

Fig. 7. Response of the ISE100 to the S\&P500 from 1 May 2003 to 8 June 2004 
The sample includes the daily observations from 23 October 1987 to 8 June 2004 and it was found that a positive shock to the US stock exchange increases the Turkish stock exchange in a statistically significant manner. The sample period is a long period for both US and Turkish markets, so the period was divided into six sub-samples. A statistically significant relationship was again found between US and Turkish stock exchanges in the sub-samples except for the period 1 January 2002 to 28 February 2003, which corresponds to the process of adaptation of new Turkish government and memorandum proposal which ended in the refusal of logistic support to United States in the war with Iraq.

\section{References}

Arshanapalli, B. and Doukas, J. (1993) International stock market linkages: evidence from the pre- and postOctober 1987 period, Journal of Banking \& Finance, 17, 193-208.

Bernanke, B. S., Hall, R. E., Leeper, E. M., Sims, C. and Zha, T. (1996) What does monetary policy do?, Brookings Papers on Economic Activity, 1996(2), $1-78$.

Byers, M. D. and Peel, D.A. (1993) Some evidence on the interdependence of national stock markets and the gains from international portfolio diversification, Applied Financial Economics, 3, 239-42.

Campbell, J. Y. and Hamao Y. (1992) Predictable stock returns in the United States and Japan: a study of long-term capital markets integration, Journal of Finance, 47, 43-70.

Cha, B. and Oh, S. (2000) The relationship between developed equity markets and the Pacific Basin's emerging equity markets, International Review of Economics and Finance, 9, 299-322.

Cheung, Y. L. and Mak, S. C. (1992) The international transmission of stock market fluctuation between the developed markets and the Asian-Pacific markets, Applied Financial Economics, 2, 43-7.

Cushman, D. O. and Zha, T. (1997) Identifying monetary policy in a small open economy under flexible exchange rates, Journal of Monetary Economics, 39, 433-48.

DeFusco, R. A., Geppert, J. M. and Tsetsekos, G. (1996) Long-run diversification potential in emerging stock markets, Financial Review, 31, 343-63.

Eun, C. S. and Shim, S. (1989) International transmission of stock market movements, Journal of Financial and Quantitative Analysis, 24, 241-56.
Felix, A. O., Dufresne, U. B. and Chatterjee, A. (1998) Investment implications of the Korean financial market reform, International Review of Financial Analysis, 7, 83-95.

Feliz, R. and Welch, J. (1997) Cointegration and tests of a classical model of inflation in Argentina, Bolivia, Mexico and Peru, Journal of Development Economics, 52(1), 189-95.

Ghosh, A., Saidi, R. and Johnson, K. H. (1999) Who moves the Asia-Pacific stock markets - US or Japan? Empirical evidence based on the theory of co-integration, The Financial Review, 34, 159-70.

Gilmore, C. G. and McMannus, G. M. (2002) International portfolio diversification: US and Central European equity markets, Emerging Markets Review, 3, 69-83.

Gordon, D. B. and Leeper, E. M. (1994) The dynamic impacts of monetary policy: an exercise in tentative identification, Journal of Political Economy, 102, 1228-47.

Hung, B. and Cheung, Y. (1995) Interdependence of Asian emerging equity markets, Journal of Finance \& Accounting, 22, 281-8.

Kamin, S. B. and Rogers, J. H. (2000) Output and the real exchange rate in developing countries: an application to Mexico, Journal of Development Economics, 61, 85-109.

Kanas, A. (1998) Linkages between the US and European equity markets: further evidence from cointegration tests, Applied Financial Economics, 8, 607-14.

Kasa, K. (1992) Common stochastic trends in international stock markets, Journal of Monetary Economics, 29, 95-124.

Liu, Y. A. and Pan, M. (1997) Mean volatility spillover effects in the US and Pacific-Basin stock markets, Multinational Finance Journal, 1, 47-62.

Phylaktis, K. and Taylor, M. (1993) Money demand, the Cagan model and the inflation tax: some Latin American evidence, The Review of Economics and Statistics, 31, 32-7.

Sewell, S. P., Stansell, S. R., Lee, I. and Below, S. D. (1996) Using chaos measures to examine international capital market integration, Applied Financial Economics, 6, 91-101.

Sims, C. A. (1992) Interpreting the macroeconomic time series facts: the effects of monetary policy, European Economic Review, 36, 975-1000.

Tokic, D. (2003) Emerging markets before the 1997 Asia Pacific financial crisis, Asia Pacific Business Review, 9(3), 105-15.

$\mathrm{Wu}, \mathrm{C}$. and $\mathrm{Su}, \mathrm{Y}$. (1998) Dynamic relations among international stock markets, International Review of Economics and Finance, 7, 63-84.

Zha, T. (1999) Block recursion and structural vector autoregressions, Journal of Econometrics, 90, 291-316. 